\title{
Activation of group II metabotropic glutamate receptors induces depotentiation in amygdala slices and reduces fear-potentiated startle in rats
}

\author{
Chia-Ho Lin, ${ }^{1}$ Chia-Ching Lee, ${ }^{1}$ Ya-Chun Huang, ${ }^{1}$ Su-Jane Wang, ${ }^{3}$ \\ and Po-Wu Gean ${ }^{1,2,4}$ \\ ${ }^{1}$ Department of Pharmacology, National Cheng-Kung University, Tainan, Taiwan 701; ${ }^{2}$ Graduate Institute of Pharmaceutical \\ Chemistry, School of Pharmacy, China Medical University, Taichung, Taiwan 404; ${ }^{3}$ School of Medicine, Fu Jen Catholic \\ University, Taipei, Taiwan 242
}

\begin{abstract}
There is a close correlation between long-term potentiation (LTP) in the synapses of lateral amygdala (LA) and fear conditioning in animals. We predict that reversal of LTP (depotentiation) in this area of the brain may ameliorate conditioned fear. Activation of group II metabotropic glutamate receptors (mGluR II) with DCG-IV induces depotentiation in the LA. The induction of depotentiation is independent of NMDA receptors, L-type $\mathrm{Ca}^{++}$ channels, and calcineurin activity, but requires presynaptic activity and extracellular $C_{a}{ }^{++}$. $\left(2 S, 2^{\prime} R, 3^{\prime} R\right)-2-\left(2^{\prime}, 3^{\prime}-\right.$ dicarboxycyclopropyl)glycine (DCG-IV) depotentiation is accompanied by a decrease in the frequency but not the amplitude of miniature excitatory post-synaptic currents (mEPSCs) and could be mimicked by endogenously released glutamate. DCG-IV inhibited the release of glutamate evoked by 4-AP but not that evoked by ionomycin, suggesting that the effect of DCG-IV is not mediated by an action downstream of $\mathrm{Ca}^{++}$entry. Intra-amygdala infusion of mGluR II agonist blocks the consolidation of fear memory measured with fear-potentiated startle. Taken together, the present results characterize the properties of DCG-IV depotentiation and reveal a close parallel between depotentiation in the amygdala slice and the reduction of conditioned fear in animals.
\end{abstract}

The metabotropic glutamate receptors (mGluRs) are G-proteincoupled receptors whose activation modulates neural activity via their linkage to multiple second-messenger systems (Pin and Duvoisin 1995; Anwyl 1999). Eight mGluRs have been cloned and classified into three groups based on their sequence homologies, signal transduction mechanisms, and agonist pharmacology (Nakanishi 1992; Pin and Duvoisin 1995). Group I (mGluR1 and mGluR5) receptors stimulate phosphatidylinositol hydrolysis, whereas group II (mGluR2 and mGluR3) and group III (mGluR4, mGluR6, mGluR7, and mGluR8) receptors are negatively coupled to cAMP production. The group II mGluRs are implicated as negative feedback autoreceptors to modulate neurotransmission by presynaptic mechanisms (Pin and Duvoisin 1995). In situ hybridization and immunohistochemical studies of rat brain have revealed that the intense mGluR II-like immunoreactivity was seen predominantly in the cortical and limbic regions including the amygdala (Neki et al. 1996; Schaffhauser et al. 1998), suggesting that these receptors may modulate higher CNS functions such as emotion and cognition. Indeed, mGluR II agonists have been shown to inhibit the release of glutamate in vivo (Battaglia et al. 1997) and exhibit potent anxiolytic effects in rats (Helton et al. 1998). These compounds also ameliorated the symptoms of nicotine withdrawal (Helton et al. 1997) and lactate-induced panic responses (Shekhar and Keim 2000). Moreover, mice lacking mGluR II display impaired hippocampal mossy fiber longterm depression (LTD) (Yokoi et al. 1996). In external capsule (EC)-basolateral amygdala synapses, it has been shown that lowfrequency stimulation (LFS) induced long-term potentiation (LTP), whereas brief high-frequency stimulation (HFS) evoked short-term potentiation that generally decayed within $10 \mathrm{~min}$.

${ }^{4}$ Corresponding author.

E-mail pwgean@mail.cmu.edu.tw; fax 886-4-2207-8083.

Article published online ahead of print. Article and publication date are at http://www.learnmem.org/cgi/doi/10.1101/lm.85304.
When LFS was applied after recovery from the short-term potentiating effect of HFS, there was an initial transient enhancement followed by LTD. The switch in the direction of the enduring change in synaptic strength required activation of mGluR II (Li et al. 1998).

LTP of synaptic responses could be reversed by LFS of afferent fibers, a phenomenon termed "depotentiation" (Barrionuevo et al. 1980; Staubli and Chun 1996). Previous studies indicated that LTP of synapses from auditory thalamus and cortex to the lateral amygdala (LA) underlay the encoding of fear memory (McKernan and Shinnick-Gallagher 1997; Rogan et al. 1997). Yet, it is not clear whether depotentiation contributes to behavioral extinction of fear memory. In the present study, we obtained evidence that activation of mGluR II induces depotentiation in rat amygdala slices. This chemical depotentiation is independent of NMDA receptor, L-type $\mathrm{Ca}^{++}$channels, and calcineurin activity, but requires presynaptic activity and extracellular $\mathrm{Ca}^{++}$. By behavioral tests, we further demonstrate that administration of mGluR II agonists to the LA or basolateral amygdala (BLA) blocks the consolidation of fear memory measured with fearpotentiated startle.

\section{Results}

Depotentiation induced by DCG-IV

Delivery of three sets of tetanic stimulation (TS, $100 \mathrm{~Hz}$ for $1 \mathrm{sec}$ ) at an interstimulus interval of $1.5 \mathrm{~min}$ to the rat EC produced a robust enhancement of synaptic responses in the LA neurons that persisted for more than $2 \mathrm{~h}$. The slopes of field excitatory postsynaptic potential (fEPSP) were $213.4 \pm 18.2 \%$ and $200.1 \pm 15.2 \%(n=6)$ of pre-tetanus level at 1 and $2 \mathrm{~h}$ after the stimulation (Fig. 1A). We investigated whether DCG-IV was able to elicit depotentiation by applying DCG-IV $(2 \mu \mathrm{M})$ for $15 \mathrm{~min}$ at $10 \mathrm{~min}$ after TS. In six experiments, the slopes of fEPSP declined 
A

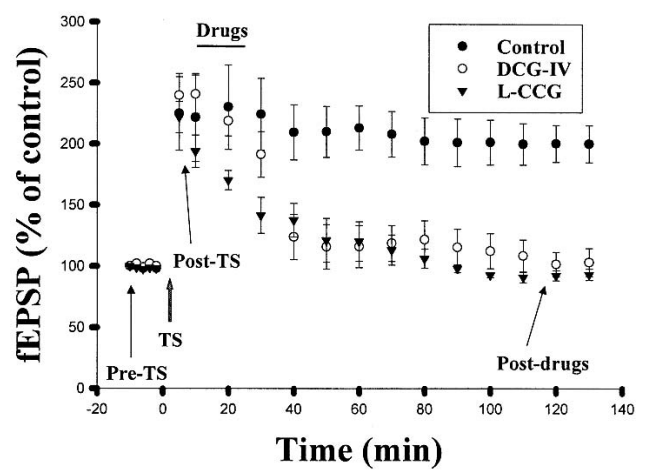

B

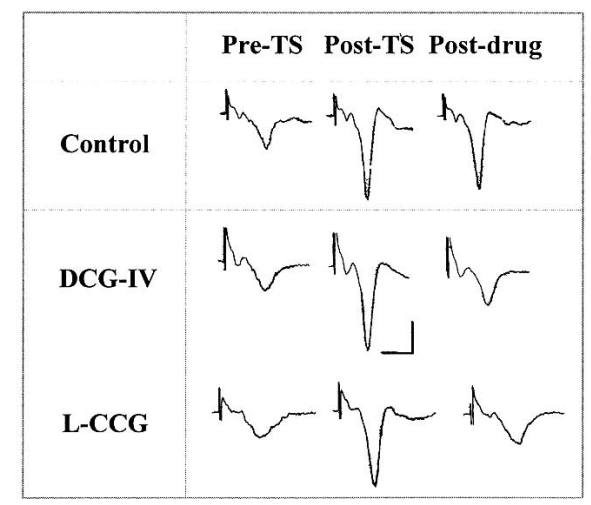

Figure 1. Activation of mGluR II-induced depotentiation in the lateral amygdala. $(A)$ The mean \pm S.E. slope of fEPSPs plotted against time. TS is marked by a gray up-arrow, and the horizontal bar represents the period of drug application. Application of DCG-IV $(2 \mu \mathrm{M})$ or L-CCG (10 $\mu \mathrm{M})$ resulted in depotentiation. $(B)$ Sample traces taken at the times indicated in $A$. Calibration: $0.5 \mathrm{mV}, 10 \mathrm{msec}$.

to $115.6 \pm 14.7 \%$ of pre-tetanus level at $1 \mathrm{~h}$ after cessation of application of DCG-IV, which was not significantly different from baseline but was significantly less than that without DCGIV treatment $\left(t_{(10)}=7.31, P<0.001\right)$. Depotentiation could also be induced by another mGluR II agonist $(2 \mathrm{~S}, 3 \mathrm{~S}, 4 \mathrm{~S})-2$ (carboxycyclopropyl) glycine (L-CCG). In four experiments, the slopes of fEPSP declined to $100.8 \pm 6.6 \%$ of baseline at $1 \mathrm{~h}$ after cessation of application of L-CCG $(10 \mu \mathrm{M})$, which was significantly less than that of control $\left(t_{(8)}=5.18, P<0.001\right)$.

We showed previously that activation of mGluR II with LCCG induced LTD at the LA-BLA synapses (Lin et al. 2000). In the present study, DCG-IV caused depotentiation without inducing LTD in cortico-LA synapses, as synaptic strength was not decreased below the pre-LTP level. We wondered whether LTD could be induced at this synapse. We therefore performed experiments to determine the relation between mGluR II-induced depotentiation and mGluR II-induced LTD. Figure 2 shows that application of DCG-IV $(2 \mu \mathrm{M})$ at $10 \mathrm{~min}$ after TS induced depotentiation. When synaptic strength returned to the pre-LTP level, a second agonist application then induced LTD, suggesting that these two forms of synaptic plasticity were not mutually occluded.

\section{Block of DCG-IV-induced depotentiation by mGluR II antagonists}

2S,1S'2S'-2-methyl-2-(2'-carboxycyclo-propyl)glycine (MCCG, $100 \mu \mathrm{M})$, a selective antagonist for mGluR II, by itself did not affect fEPSP $(97.8 \pm 3.5 \%$ of control, $n=6, P>0.1)$. However, as shown in Figure 3A, it blocked depotentiation induced by DCGIV. In the presence of MCCG, the slope of fEPSP was $196.0 \pm 14.1 \%(n=6)$ of pre-tetanus level at $1 \mathrm{~h}$ after cessation of DCG-IV, which was not different from control without DCG-IV treatment $\left(t_{(10)}=1.32, P=0.22\right)$ but was significantly greater than that treated with DCG-IV alone $\left(t_{(10)}=5.98, P<0.001\right)$.

Another mGluR II antagonist (2S)- $\alpha$-ethylglutamic acid (EGLU) (Jane et al. 1996) was examined. Consistent with a previous report (Li et al. 1998), EGLU $(10 \mu \mathrm{M})$ did not affect synaptic responses in the amygdala $(101 \pm 1 \%$ of control, $n=6)$ but blocked the depotentiating effect of DCG-IV (Fig. 3A). In the presence of EGLU, the slope of fEPSP was $205.5 \pm 19.4 \%$ of pretetanus level at $1 \mathrm{~h}$ after cessation of DCG-IV, which was significantly different from that without EGLU treatment $\left(t_{(10)}=5.49\right.$, $P<0.001)$. In the same vein, in the presence of a highly selective mGluRII antagonist, LY341495 $(20 \mu \mathrm{M})$, the slope of fEPSP was $174.2 \pm 6.6 \%$ of pre-tetanus level at $1 \mathrm{~h}$ after cessation of DCGIV, which was significantly different from that without LY341495 treatment $\left(t_{(9)}=11.11, P<0.001\right)$.

\section{DCG-IV-induced depotentiation is independent of NMDA receptor and VDCC activation}

To examine whether NMDA receptor plays a role in DCG-IVinduced depotentiation, NMDA receptor antagonist D-APV was applied. Since in our experimental conditions D-APV also blocked the induction of LTP, D-APV was applied at 5 min after TS. DCG-IV was then given at 5 min after D-APV perfusion, and both drugs were removed following a 15-min application of DCG-IV. We found that D-APV $(50 \mu \mathrm{M})$ did not affect depotentiation. The fEPSP measured at $1 \mathrm{~h}$ after cessation of DCG-IV was $99.7 \pm 10.2 \%(n=6)$ of pre-tetanus value, which was not different from that without D-APV application $\left(t_{(10)}=0.19, P=0.88\right)$.

Some NMDA-independent forms of synaptic plasticity in the amygdala depend on L-type voltage-dependent $\mathrm{Ca}^{++}$channels (VDCCs) (Weisskopf et al. 1999; Bauer et al. 2002). We tested whether inhibition of L-type VDCCs affected amygdala depotentiation. Blocking L-type VDCCs with nimodipine $(2 \mu \mathrm{M})$ did not affect DCG-IV depotentiation (Fig. 3A). The fEPSP slope was $100.6 \pm 6.9 \%(n=6)$ of baseline at $1 \mathrm{~h}$ after cessation of DCG-IV, which was not significantly different from that without nimodipine treatment $\left(t_{(10)}=0.11, P=0.92\right)$.

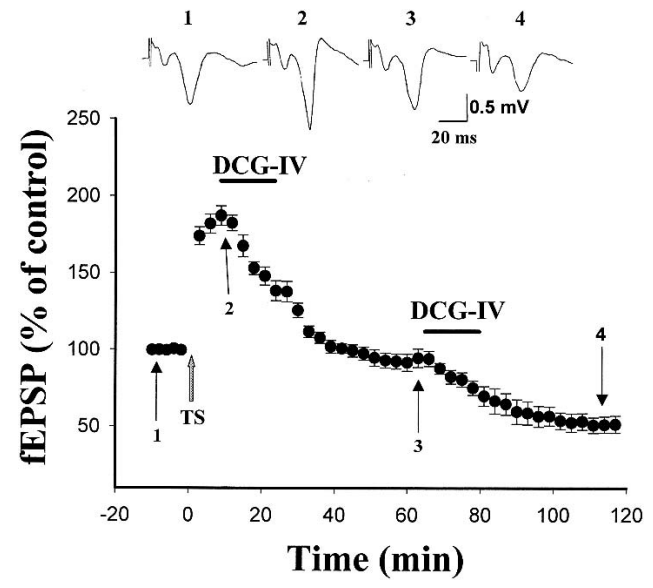

Figure 2. DCG-IV-induced depotentiation and LTD are not mutually occluded. Application of DCG-IV $(2 \mu \mathrm{M})$ at $10 \mathrm{~min}$ after TS induced depotentiation. When synaptic strength returned to the pre-LTP level, a second agonist application induced LTD. 


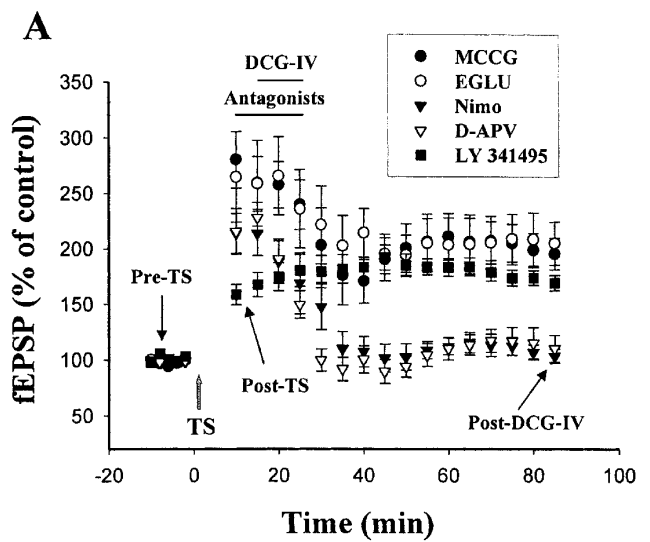

B

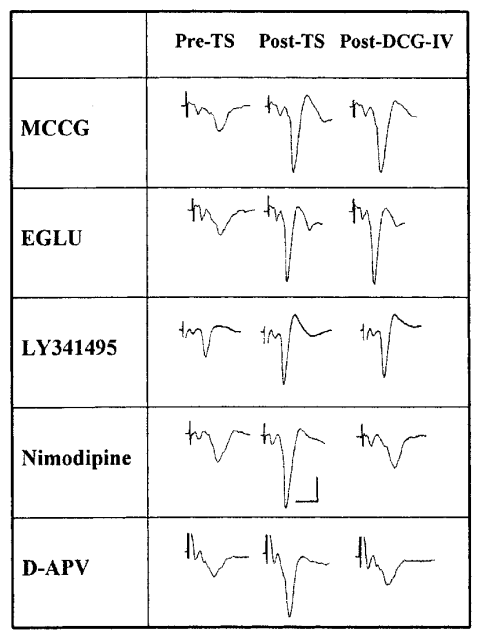

Figure 3. Blockade of DCG-IV-induced depotentiation by mGluR II antagonists but not by L-type $\mathrm{Ca}^{++}$channel or NMDA receptor antagonists. (A) Application of DCG-IV $(2 \mu \mathrm{M})$ in the presence of MCCG $(100$ $\mu \mathrm{M})$, EGLU $(10 \mu \mathrm{M})$, or LY341495 $(20 \mu \mathrm{M})$ failed to cause depotentiation. In contrast, DCG-IV induced a normal depotentiation in the presence of nimodipine $(2 \mu \mathrm{M})$ or D-APV $(50 \mu \mathrm{M})$. (B) Sample traces taken the times indicated in $A$. Calibration: $0.5 \mathrm{mV}, 10 \mathrm{msec}$.

\section{Presynaptic mechanism for DCG-IV depotentiation}

To characterize the site of action, we used whole-cell voltage clamp $\left(\mathrm{V}_{\mathrm{h}}=-70 \mathrm{mV}\right)$ to record miniature excitatory postsynaptic currents (mEPSCs) in the presence of the $\mathrm{Na}^{+}$channel blocker tetrodotoxin (TTX, $1 \mu \mathrm{M}$ ) and the $\mathrm{GABA}_{\mathrm{A}}$ receptor antagonist bicuculline $(1 \mu \mathrm{M})$. A decrease in the frequency of mEPSCs is interpreted to be a result of presynaptic action (e.g., a reduction in the probability of neurotransmitter release or in the number of quanta available for release), whereas a decrease in the amplitude normally indicates a reduction in the post-synaptic sensitivity to the transmitter. The result is summarized in Figure $4 \mathrm{D}$, for the experiment in which DCG-IV $(2 \mu \mathrm{M})$ was applied for $15 \mathrm{~min}$; the frequency and amplitude of mEPSCs measured in the presence of DCG-IV were $49.0 \pm 5.5 \%(n=6, P<0.01)$ and $98.0 \pm 2.6 \%$ ( $n=6, P>0.1)$ of control, respectively. These results suggest that an activity-mediated change in pre- but not post-synaptic $\mathrm{Ca}^{++}$ level is required for DCG-IV depotentiation.

We directly monitored glutamate release from purified amygdala synaptosomes using an assay employing exogenous glutamate dehydrogenase and $\mathrm{NADP}^{+}$to couple the oxidative deamination of released glutamate to the generation of NADPH. Figure 5A shows that, under control conditions, 4-aminopyridine
(4-AP, $3 \mathrm{mM}$ ) evoked glutamate release of $39.9 \pm 1.9 \mathrm{nmol} / \mathrm{mg} / 6$ min $(n=6)$. Pre-incubation of synaptosomes with DCG-IV significantly reduced the release of glutamate $\left(F_{(2,15)}=27.5\right.$, $P<0.001)$. The effect of DCG-IV was concentration-dependent, with 2 and $6 \mu \mathrm{M}$ decreasing glutamate release to $32.2 \pm 0.6$ $(n=5, P<0.01)$ and $26.3 \pm 1.0(n=7, P<0.001) \mathrm{nmol} / \mathrm{mg} / 6$ min, respectively. The reduction of glutamate release could occur by blocking $\mathrm{Ca}^{++}$entry through VDCCs or by inhibiting release machinery downstream of $\mathrm{Ca}^{++}$entry. To further differentiate these mechanisms, we triggered transmitter release using the $\mathrm{Ca}^{++}$ionophore ionomycin, which causes a direct increase in intrasynaptosomal $\mathrm{Ca}^{++}$without previous depolarization and $\mathrm{Ca}^{++}$channel activation (Capogna et al. 1996). Figure 5B shows that ionomycin $(5 \mu \mathrm{M})$ caused glutamate release of $32.6 \pm 0.4$ $\mathrm{nmol} / \mathrm{mg} / 6 \mathrm{~min}(n=6)$. In the presence of DCG-IV $(2 \mu \mathrm{M})$, ionomycin-induced release of glutamate was not significantly affected $(32.3 \pm 1.2 \mathrm{nmol} / \mathrm{mg} / 6 \mathrm{~min}, n=6, P=0.80)$, suggesting that the effect is not mediated via an action downstream of $\mathrm{Ca}^{++}$ entry.

\section{Requirements of synaptic activity and $\mathrm{Ca}^{++}$entry for DCG-IV depotentiation}

To determine whether synaptic activity was required for DCG-IV depotentiation, experiments were carried out in which synaptic stimulation was ceased both during the application of DCG-IV and 10 min after the washout, thereby avoiding $\mathrm{Ca}^{++}$entry into presynaptic boutons during application of DCG-IV. As shown in Figure 6A, DCG-IV did not induce depotentiation in the absence of synaptic stimulation. At $1 \mathrm{~h}$ after cessation of application of DCG-IV, fEPSP slopes were $221.7 \pm 21.6 \%(n=6)$ of pre-tetanus level, which was significantly different from that for simultaneous application of DCG-IV with synaptic stimulation $\left(t_{(10)}=5.55, P<0.001\right)$.

To determine whether a rise in presynaptic $\mathrm{Ca}^{++}$is required for the action of DCG-IV, we applied DCG-IV $(2 \mu \mathrm{M})$ in the absence of extracellular $\mathrm{Ca}^{++}$by incubation of slices in $\mathrm{Ca}^{++}$-free solution. As shown in Figure 6B, DCG-IV in $\mathrm{Ca}^{++}$-free solution no longer induced depotentiation. At $1 \mathrm{~h}$ after cessation of application of DCG-IV, fEPSP slopes were $197.4 \pm 13.6 \%(n=6)$ of pretetanus level, which was significantly different from that in normal Ca ${ }^{++}$solution $(P<0.001)$.

\section{Depotentiation induced by endogenously released glutamate}

We investigated whether endogenously released glutamate is capable of diffusing to the presynaptic terminals and induced depotentiation by acting at mGluR II. Since synaptically released glutamate is removed from extracellular space by a re-uptake mechanism, to investigate a role for endogenously released glutamate, experiments were performed under the condition of blocking re-uptake of glutamate with L-trans-pyrrolidine-2,4dicarboxylic acid (trans-PDC). Because activation of postsynaptic NMDA receptors with low-frequency stimulation could induce depotentiation, kynurenic acid was applied to block postsynaptic glutamate receptors. Thus, trans-PDC $(100 \mu \mathrm{M})$ and kynurenic acid $(1 \mathrm{mM})$ were co-applied at $5 \mathrm{~min}$ after TS, and the release of glutamate was evoked by repetitive afferent stimulation $(10 \mathrm{~Hz}$ for $90 \mathrm{sec})$ at $10 \mathrm{~min}$ after TS. Figure 7A shows that glutamate released by repetitive stimulation caused a significant depotentiation. The fEPSP measured at $2 \mathrm{~h}$ after TS was $116.9 \pm 11.4 \%(n=6)$ of the pre-tetanus value, which was significantly different from those without stimulation (159.6 \pm 7.0, $n=8, P<0.005)$. Furthermore, repetitive stimulation-induced depotentiation was reduced by EGLU $(167.5 \pm 10.0 \%, n=5$, $P<0.01)$, suggesting the involvement of mGluR II.

\section{Learning \& Memory \\ www.learnmem.org}


A

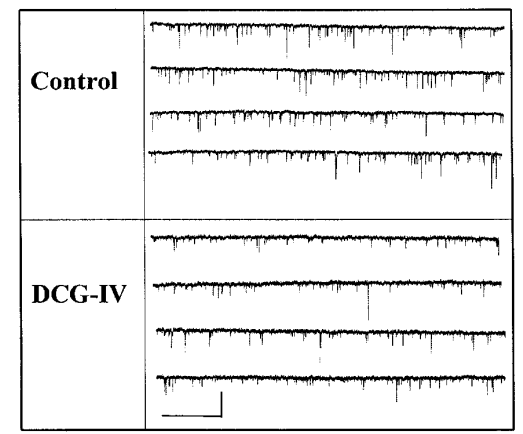

B

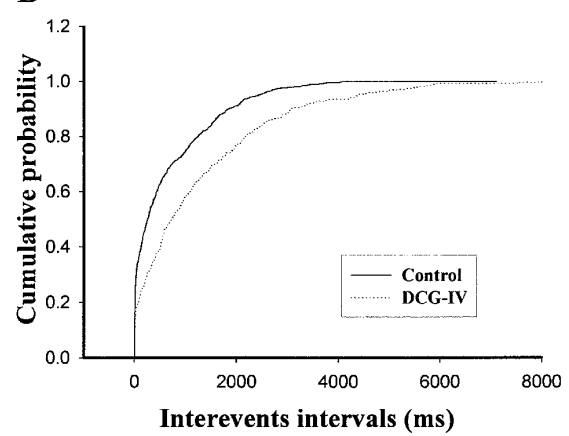

C

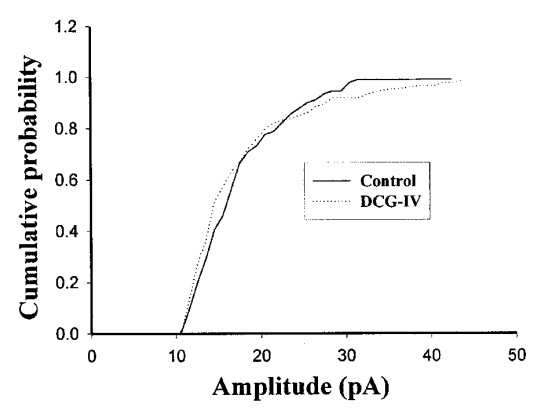

D

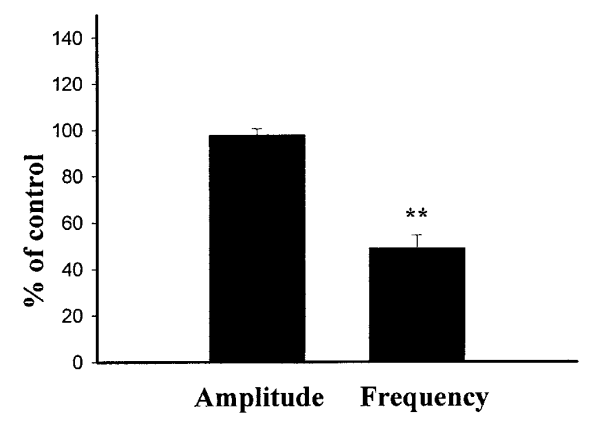

Figure 4. DCG-IV decreases the frequency but not the amplitude of mEPSCs. (A) Sample traces of mEPSCs recorded in the presence of TTX $(1 \mu \mathrm{M})$ and bicuculline $(1 \mu \mathrm{M})$. Traces were taken before and in the presence of DCG-IV $(2 \mu \mathrm{M})$. Calibration: $50 \mathrm{pA}, 6 \mathrm{sec}$. (B) Cumulative plot of inter-event intervals of EPSCs. (C) Cumulative plot of amplitude of EPSCs. (D) The frequency of mEPSCs after treatment with DCG-IV was significantly lower than that of control, whereas the amplitude of mEPSCs was unaffected. $* \star P<0.01$ vs. control.

\section{DCG-IV reduces fear-potentiated startle}

Rats were trained with 10 pairs of light (conditioned stimulus, CS) and footshock (unconditioned stimulus, US), and retention of memory was tested $24 \mathrm{~h}$ later (pre-test). After initial training, rats exhibited fear (of the light) that was manifested as an increase in acoustic startle. They were subsequently divided into two groups, DCG-IV and vehicle control groups. The DCG-IV group received bilateral infusion of DCG-IV (1 nmol in $2 \mu \mathrm{L}$ DMSO, $1 \mu \mathrm{L}$ per side) to the amygdala $1 \mathrm{~h}$ after pre-test, and retested $23 \mathrm{~h}$ later (Fig. 8A). Figure $8 \mathrm{~B}$ shows that the mean startle potentiation after infusion with DCG-IV was significantly reduced compared to the pre-test value $\left(t_{(5)}=3.44, P<0.01\right)$. To demonstrate that the effect of DCG-IV was attributable to genuine interaction with mGluRII receptors, DCG-IV was coadministered with LY341495 (2 $\mu$ g dissolved in $2 \mu \mathrm{L}$ DMSO, $1 \mu \mathrm{L}$ per side). As shown in Figure 8B, LY341595 by itself did not affect the startle potentiation $\left(t_{(4)}=0.45, P=0.34\right)$ but blocked DCGIV-induced reduction of fear-potentiated startle. There was no difference between pre- and post-tests $\left(t_{(4)}=0.54, P=0.31\right)$ in rats treated simultaneously with DCG-IV and LY 341595. Furthermore, infusion of DCG-IV ( $1 \mathrm{nmol}$ in $2 \mu \mathrm{L}$ DMSO, $1 \mu \mathrm{L}$ per side) bilaterally to the amygdala at $6 \mathrm{~h}$ instead of $1 \mathrm{~h}$ after conditioning had no significant effect on the startle amplitude (pretest, $218.7 \pm 55.7 \%$; post-test, $159.7 \pm 82.1 \%, n=6, P=0.56$ ), suggesting that the amnesic effect of DCG-IV was caused primarily by the impairment of memory consolidation processes. Electrode tip locations in these experiments are shown in the Figure 8C. Only rats with cannula tips at or within the boundaries of the LA and BLA were included in the data analysis. Figure 8D illustrates the dose-dependent effect of DCG-IV when applied at $1 \mathrm{~h}$ after pre-test. The ANOVA for startle scores revealed a significant effect for dose $\left(F_{(4,22)}=9.66, P<0.001\right)$. Newman-Keuls $t$-tests revealed that significant differences existed between vehicle control and the high doses $(0.5$, 1.0 , and $2.5 \mathrm{nmol})$ of DCG-IV $(P<0.01)$, whereas no difference was detected between control and low doses $(0.1 \mathrm{nmol}$; $P>0.05)$.

Since DCG-IV reduced startle reflex at $1 \mathrm{~h}$ but not $6 \mathrm{~h}$ after conditioning, we investigated the time-dependent reversal of LTP by DCG-IV. LTP was elicited by three sets of TS and, $10 \mathrm{~min}$ or $60 \mathrm{~min}$ after the TS, DCG-IV $(2 \mu \mathrm{M})$ was applied for $15 \mathrm{~min}$. Figure 8E shows that, when DCG-IV was applied at $60 \mathrm{~min}$ after TS, the slope of fEPSP at $140 \mathrm{~min}$ after TS was $153.5 \pm 22.9(n=5)$ of baseline, which was significantly different from that when DCG-IV was applied at 10 min after TS $(103.4 \pm 11.4, n=5$, $P<0.005)$.

\section{Discussion}

The observation that Gulf War veterans with post-traumatic stress disorder exhibited an exaggerated acoustic startle reflex (Morgan et al. 1996) proves the relevance of fear conditioning to human fear and anxiety states. Since fear conditioning is expressed by LTP of synaptic transmission in the amygdala (McKernan and Shinnick-Gallagher 1997; Rogan et al. 1997), depotentiation in this area of the brain may represent an important mechanism for amelioration of anxiety. However, synaptic stimulation is not amenable for routine treatment. A better pharmacological strategy for treating anxiety disorders is needed. In the present study, we characterized the cellular mechanism of chemical depotentiation at the EC-LA synapse that is important for mediation of fear conditioning. We found that activation of mGluR II with DCG-IV induced depotentiation. The blockade of DCG-IV depotentiation by the selective mGluR II antagonists MCCG, EGLU, and LY341495 confirms the mediation by mGluR II. In behavioral tests, bilateral infusion of DCG-IV into the amygdala impaired consolidation of fear conditioning in an mGluR II-dependent manner. In view of the fact that systemic or intra-amygdala administration of a partial NMDA receptor agonist, D-cycloserine, facilitates extinction of fear memory (Walker et al. 2002), DCG-IV could act as an NMDA receptor agonist to induce depotentiation and reduce fear-potentiated startle. However, the concentration of DCG-IV used in the present study $(2 \mu \mathrm{M})$ is lower than the concentrations at which the drug was shown to act as an NMDA receptor agonist $(>10 \mu \mathrm{M})$ (Ishida et al. 1993; Wilsch et al. 1994). Taken together, the parallel effects of DCG-IV on LTP in the in vitro slices and consolidation of fear memory in vivo provide direct evidence that synaptic plasticity and memory storage are subjected to regulation by mGluR II in the amygdala.

We recently reported that depotentiation could be induced in the same synapse by LFS (Lin et al. 2003). Although DCG-IV depotentiation described here is phenomenologically similar to that of LFS depotentiation, the underlying cellular mechanisms appear to be quite different. LFS depotentiation requires activation of NMDA receptors, depends on post-synaptic calcineurin 


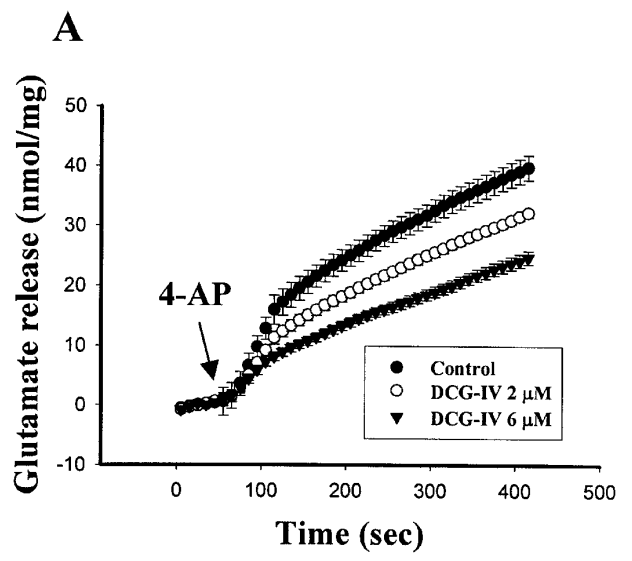

\section{B}

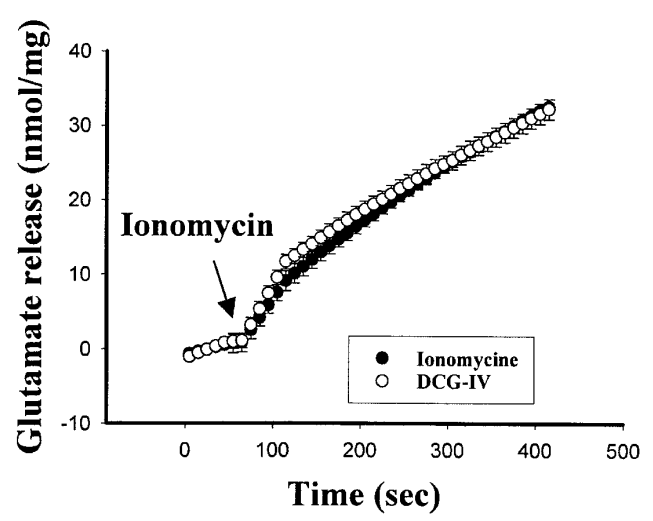

Figure 5. DCG-IV inhibits glutamate release evoked by 4-AP but not by ionomycin. (A) Amygdala synaptosomes $(0.3 \mathrm{mg} / \mathrm{mL})$ were preincubated for $10 \mathrm{~min}$ with DCG-IV $(2$ and $6 \mu \mathrm{M})$ followed by the addition of 4-AP (3 $\mathrm{mM})$. (B) DCG-IV $(2 \mu \mathrm{M})$ had no effect on ionomycin $(5 \mu \mathrm{M})$-evoked glutamate release. Glutamate release was assayed by on-line fluorometry.

activity, and is independent of presynaptic phenomenon of paired-pulse facilitation. In contrast, DCG-IV depotentiation is independent of NMDA receptors, L-type $\mathrm{Ca}^{++}$channels, and calcineurin activity, but is dependent on presynaptic activity and extracellular $\mathrm{Ca}^{++}$influx. One way to differentiate pre- vs. postsynaptic $\mathrm{Ca}^{++}$influx in DCG-IV depotentiation is to determine the effect of injecting $\mathrm{Ca}^{++}$chelator (BAPTA) into post-synaptic neurons on the action of DCG-IV. However, a requirement of post-synaptic $\mathrm{Ca}^{++}$increase for LTP induction has precluded us from doing this experiment. Nonetheless, two lines of evidence favor the presynaptic mechanism: (1) DCG-IV depotentiation was associated with a decrease in the frequency but not the amplitude of mEPSCs, and (2) DCG-IV inhibited the release of glutamate evoked by 4 -AP in a concentration-dependent manner, whereas ionomycin-evoked glutamate release was not affected.

The involvement of mGluR II in long-term synaptic plasticity (e.g., long-term depression, LTD) has been documented in several brain areas including the amygdala (Heinbockel and Pape 2000; Lin et al. 2000). The present results are consistent with the view that mGluR II is presynaptically located and that its activation results in a long-term decrease in glutamate release (Tzounopoulos et al. 1998; Kobayashi et al. 1999; Lin et al. 2000; Robbe et al. 2002). However, immunohistological studies indicate that mGluRs II exist not only at a presynaptic site but also locate post-synaptically (Neki et al. 1996). Indeed, activation of postsynaptic mGluR II in the hippocampal dentate gyrus, perirhinal and prefrontal cortices has been shown to induce LTD. The un- derlying mechanisms involved post-synaptic PKC activation and an $\mathrm{IP}_{3}$ receptor-mediated post-synaptic increase of $\mathrm{Ca}^{++}$concentration (Huang et al. 1999; Cho et al. 2000; Otani et al. 2002). In the lateral amygdala, Heinbockel and Pape (2000) showed that LTD induced by LFS of thalamic input fibers was occluded by mGluR II agonist and was blocked in neurons loaded with BAPTA, suggesting a post-synaptic site of action. The reason(s) for the difference between their results and ours is not clear. It could be attributable to the sites of synaptic stimulation; they stimulated thalamic input fibers whereas we stimulated putative cortical input.

In summary, fear conditioning or TS resulted in a large amount of glutamate release and an influx of $\mathrm{Ca}^{++}$into cells through NMDA receptors or L-type $\mathrm{Ca}^{++}$channels (Miserendino et al. 1990; Maren 1999; Weisskopf et al. 1999), leading to the activation of protein kinases (Lin et al. 2001; Schafe et al. 2001). Once stimulated, protein kinases caused phosphorylation of GluR 1 to increase synaptic function of AMPA receptors by altering channel properties and/or promoting the exocytosis (Soderling and Derkach 2000). Activated kinases can also translocate to the nucleus and subsequently stimulate transcription factors to promote gene transcription and new protein synthesis (Impey et al. 1998; Schafe et al. 2000; Josselyn et al. 2001). DCG-IV acted by
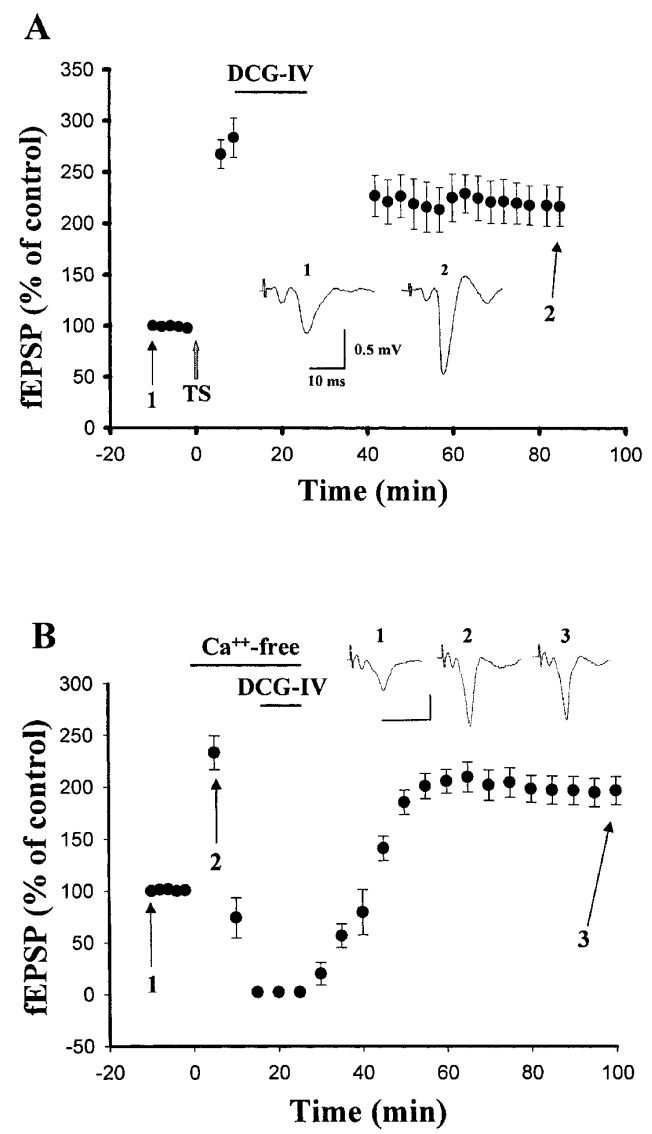

Figure 6. DCG-IV depotentiation is dependent on presynaptic activity and is blocked by $\mathrm{Ca}^{++}$-free solution. (A) Summary of six experiments showing that DCG-IV depotentiation was blocked when synaptic stimulation was stopped both during the application of DCG-IV $(2 \mu \mathrm{M})$ and 10 min after the washout. Inset: The traces taken at the time points indicated. (B) Summary of six experiments showing that DCG-IV failed to induce depotentiation when the medium was changed to $\mathrm{Ca}^{++}$-free solution 14 min before and during the application of DCG-IV $(2 \mu \mathrm{M})$. Inset: The traces taken at the time points indicated. Calibration: $0.5 \mathrm{mV}, 20$ msec.

\section{Learning \& Memory}


A
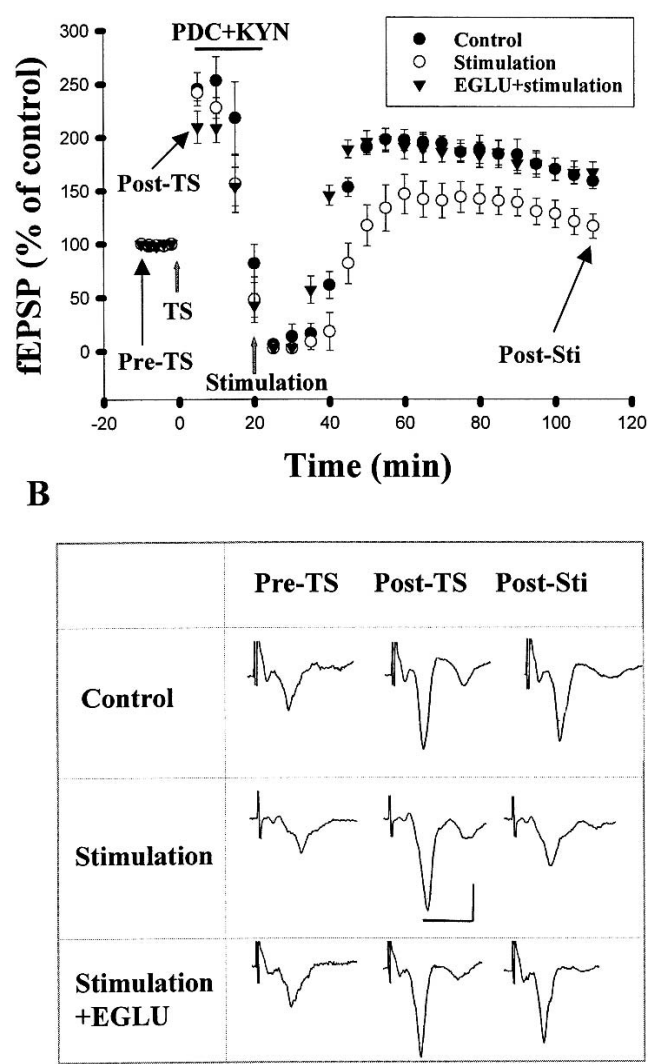

Figure 7. Depotentiation induced by endogenously released glutamate. $(A)$ In the presence of kynurenic acid $(1 \mathrm{mM})$ and the glutamate uptake inhibitor trans-PDC $(100 \mu \mathrm{M})$, repetitive afferent stimulation (10 $\mathrm{Hz}$ for $90 \mathrm{sec}$ ) at $10 \mathrm{~min}$ after TS caused a significant depotentiation that could be blocked by EGLU $(10 \mu \mathrm{M})$. (B) Sample traces taken at the times indicated in $A$. Calibration: $0.5 \mathrm{mV}, 10 \mathrm{msec}$.

decreasing glutamate release, which in turn caused depotentiation. The findings that (1) activation of mGluR II caused timedependent depotentiation, and (2) infusion of DCG-IV to the amygdala at $1 \mathrm{~h}$ but not at $6 \mathrm{~h}$ after training inhibited conditioned fear suggest interference with consolidation processes. Altogether, our results could provide important clues to develop more effective pharmacological strategies for treating neuronal disorders resulting from amygdala overexcitation such as epilepsy (Neugebauer et al. 1997; Keele et al. 1999), fear, and anxiety.

\section{Materials and Methods}

\section{Slice preparation and electrophysiological recordings}

Male Sprague-Dawley rats ( $\sim 5-7$-wk-old) were decapitated and their brains rapidly removed and placed in cold oxygenated artificial cerebrospinal fluid (ACSF) solution. Subsequently, the brain was hemisected and cut transversely posterior to the first branch and anterior to the last branch of the superior cerebral vein. The resulting section was glued to the chuck of a Vibroslice tissue slicer (Campden Instruments). Transverse slices of $450 \mu \mathrm{m}$ thickness were cut and the appropriate slices placed in a beaker of oxygenated ACSF at room temperature for at least $1 \mathrm{~h}$ before recording. ACSF solution had the following composition (in $\mathrm{mM}$ ): $\mathrm{NaCl} 117, \mathrm{KCl} 4.7, \mathrm{CaCl}_{2} 2.5, \mathrm{MgCl}_{2} 1.2, \mathrm{NaHCO}_{3} 25$, $\mathrm{NaH}_{2} \mathrm{PO}_{4} 1.2$, and glucose 11 . The ACSF was bubbled continuously with $95 \% \mathrm{O}_{2}-5 \% \mathrm{CO}_{2}$ and was $\mathrm{pH} 7.4$.

A single slice was transferred to the recording chamber, in which it was held submerged between two nylon nets and maintained at $32 \pm 1{ }^{\circ} \mathrm{C}$. The chamber consisted of a circular well of a low volume (1-2 mL) and was perfused constantly at a rate of 2-3 $\mathrm{mL} / \mathrm{min}$. Extracellular field potentials were made by electrical stimulation of the external capsule (EC), which contained fibers from the auditory cortex to the lateral amygdala, with a concentric bipolar stimulating electrode (SNE-100, Kopf Instruments). Electrical stimuli $(150 \mu \mathrm{sec}$ in duration) were delivered at a frequency of $0.05 \mathrm{~Hz}$. Baseline field potentials were adjusted to $\sim 30 \%-40 \%$ of the maximal responses. LTP was elicited by three trains of tetanus $(100 \mathrm{~Hz}, 1 \mathrm{sec}$ at 1.5 -min intervals) at the same stimulation intensity used for baseline. Bicuculline $(1 \mu \mathrm{M})$ was present in the perfusion solution to facilitate the induction of LTP.

Whole-cell patch-clamp recordings were made from the LA thin slices $(200 \mu \mathrm{m})$. Patch electrodes were pulled from a thickwall glass capillary $(0.75 \mathrm{~mm}$ I.D., $1.5 \mathrm{~mm}$ O.D.) to a tip resistance of 2-5 $\mathrm{M} \Omega$. The composition of the internal solution was (in mM): GTPtris 0.33, K-gluconate $125, \mathrm{KCl} \mathrm{5,} \mathrm{BAPTA} \mathrm{5,} \mathrm{CaCl}_{2}$ $0.5, \mathrm{MgATP} 5$, HEPES 10 . The final $\mathrm{pH}$ of the internal solution was adjusted to 7.2 by adding $1 \mathrm{M} \mathrm{KOH}$; the final osmolarity was adjusted to 280 mOsm by adding sucrose. Records were low-passfiltered at $2.5-20 \mathrm{kHz}$ and digitized at $5-50 \mathrm{kHz}$. The signal was monitored and recorded with an Axopatch 200B amplifier (Axon Instruments). Online analysis and control of experimental acquisition were accomplished via a Pentium 3-based PC clone and a Digidata 1320 computer interface. All data are expressed as mean \pm standard error. The data were analyzed with ANOVA and Student's $t$-test, and $P<0.05$ was considered significant. Drugs were applied directly to the ACSF using a continuous gravity-fed bath application, and the concentration of applied drug reached equilibrium within 2-3 min. L-CCG and D-APV were obtained from Research Biochemicals International. DCG-IV, MCCG, EGLU, and LY 341495 were obtained from Tocris Cookson; nimodipine was obtained from Sigma.

\section{Surgery}

Rats ( $\sim 6$ wks old) were anesthetized with sodium pentobarbital (50 mg/kg, i.p.) and then mounted on a stereotaxic apparatus. Two cannula made of 22-gauge stainless steel tubing (C313G, Plastic Products) were implanted bilaterally into the LA or BLA [anteroposterior (AP), $-2.8 \mathrm{~mm}$; mediolateral (ML), $\pm 4.5 \mathrm{~mm}$; dorsoventral (DV), -7.0 mm] (Paxinos and Watson 1986). A 28gauge dummy cannula was inserted into each cannula to prevent clogging. Three jewelry screws were implanted over the skull serving as anchors, and the whole assembly was affixed on the skull with dental cement. The rats were monitored and handled daily and were given $7 \mathrm{~d}$ to recover.

\section{Fear conditioning}

The startle response was measured in a startle apparatus (San Diego Instruments) as described by Lu et al. (2001). Briefly, rats were constrained in a Plexiglas cylindrical tube (length $20 \mathrm{~cm}$, diameter $10 \mathrm{~cm}$ ) with an accelerometer sensor attached on the base. The whole set-up was enclosed in a ventilated, soundattenuating cabinet (length $38 \mathrm{~cm}$, width $38 \mathrm{~cm}$, and height 55 $\mathrm{cm}$ ). The acoustic startle stimulus was $50 \mathrm{msec}$ white-noise at the intensity of $95 \mathrm{~dB}$ delivered by a speaker $30 \mathrm{~cm}$ above the animal. The visual CS was a 3.7-sec light produced by an $8 \mathrm{~W}$ fluorescent bulb. The US was a $0.6 \mathrm{~mA}$ footshock of $0.5 \mathrm{sec}$ duration. All data were reserved for off-line analyses.

\section{Acclimation}

On three consecutive days, rats were placed in the startle test boxes for $10 \mathrm{~min}$ and then returned to their home cages.

\section{Matching}

On two consecutive days, rats were placed in the startle box and 3 min later presented with 10 startle stimuli at 2-min intertrial intervals (ITI). On the basis of their mean startle amplitudes in the second of these two sessions, rats were matched into groups with similar response levels. 
A
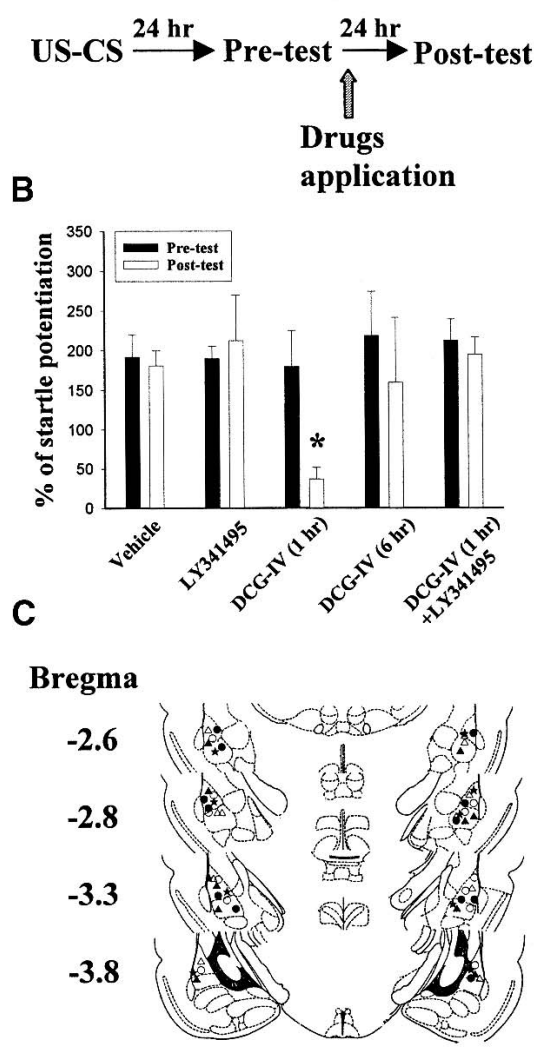

D

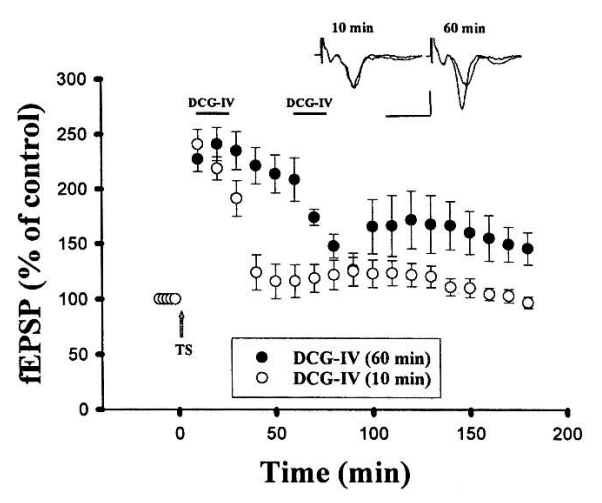

E

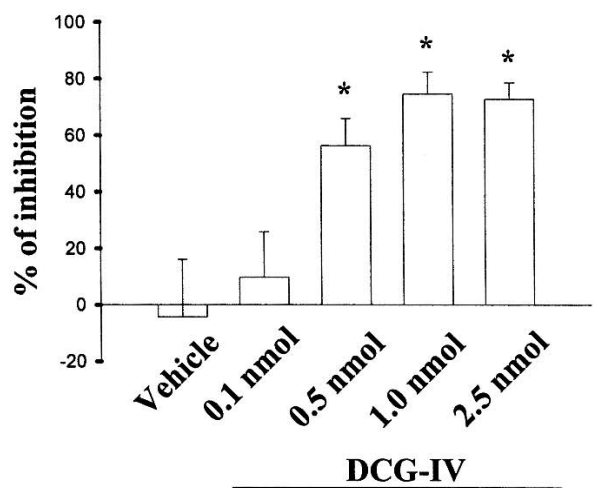

Figure 8. DCG-IV reduces fear-potentiated startle. $(A)$ Behavioral procedure used. $(B)$ Comparison of startle potentiation between pre- and post-DCG-IV tests. Intra-amygdala infusion of DCG-IV (1 nmol in $2 \mu \mathrm{L}$ DMSO, $1 \mu \mathrm{L}$ per side) at $1 \mathrm{~h}$ but not $6 \mathrm{~h}$ after conditioning significantly reduced fear-potentiated startle. This effect could be reversed by co-administration of mGluR II antagonist LY 341495 (2 $\mu \mathrm{g}$ dissolved in $2 \mu \mathrm{L}$ DMSO, $1 \mu \mathrm{L}$ per side). ${ }^{*} P<0.01$ vs. pre-DCG-IV tests. (C) Electrode tip placements in vehicle control (O), LY341495 (•), DCG-IV applied at $1 \mathrm{~h}$ after conditioning $(\triangle)$, DCG-IV plus LY341495 $(\boldsymbol{\Delta})$, and DCG-IV applied at $6 \mathrm{~h}$ after conditioning $(\star)$. $(D)$ Dose-dependent inhibition of fearpotentiated startle by DCG-IV. ${ }^{*} P<0.01$ vs. control. $(E)$ DCG-IV $(2 \mu \mathrm{M})$ applied at $60 \mathrm{~min}$ after TS caused less depotentiation than when applied at 10 min after TS.

\section{Training}

Rats were placed in the startle boxes and following a 5 minacclimation period received 10 light-footshock pairings with a 2-min ITI. Unpaired controls received the same number of light and footshock presentation, but in a pseudorandom fashion in which the US could occur at anytime except at the $3.2 \mathrm{sec}$ following the CS.

\section{Pretest}

Twenty-four hours after training, rats were tested for fearpotentiated startle. This involved 30 startle-eliciting noise bursts presented alone (noise-alone trial) and 30 noise bursts presented $3.2 \mathrm{sec}$ after onset of the $3.7 \mathrm{sec}$ light (light-noise trials). The two trial types were presented in a balanced mixed order (ITI, $30 \mathrm{sec}$ ). The percentage of fear-potentiated startle was computed as follows: [(startle amplitude on CS-noise minus noise-alone trials)/ (noise-alone trials) $] \times 100$.

\section{Drug application}

The drugs were administered bilaterally in a volume of $1.0 \mu \mathrm{L}$ at a rate of $0.5 \mu \mathrm{L} / \mathrm{min}$ using 28 -gauge infusion cannulas that extended $1.0 \mathrm{~mm}$ from the base of the guide. The infusion cannulas were attached to a $10-\mu \mathrm{L}$ Hamilton syringe and, after the infusion, the cannulas were left in place for 1-3 min to allow diffusion of the drugs from the tip.
Post-test

Twenty-three hours after drug application, rats were tested for fearpotentiated startle in a procedure identical to the pretest.

Preparation of synaptosomes and glutamate release assay

Synaptosomes were prepared from the lateral and basolateral nucleus of the amygdala according to the method described (Wang et al. 2001). The final synaptosomal pellet was resuspended in incubation buffer (HBM) consisting of $140 \mathrm{mM} \mathrm{NaCl}, 5 \mathrm{mM} \mathrm{KCl}, 5 \mathrm{mM}$ $\mathrm{NaHCO}_{3}, 1 \mathrm{mM} \mathrm{MgCl}{ }_{2} \cdot 6 \mathrm{H}_{2} \mathrm{O}, 1.2 \mathrm{mM}$ $\mathrm{Na}_{2} \mathrm{HPO}_{4}, 10 \mathrm{mM}$ glucose, $10 \mathrm{mM}$ HEPES, and $1 \mathrm{mg} / \mathrm{mL}$ BSA (pH 7.4). The protein concentration was determined using the Bradford assay. Synaptosomes were centrifuged in the final wash to obtain synaptosomal pellets with $0.3 \mathrm{mg}$ protein. Synaptosomal pellets were stored on ice and used within 2-3 h.

Synaptosomal pellets were resuspended in incubation buffer in a stirred and thermostated cuvette maintained at $37^{\circ} \mathrm{C}$ in a Perkin-Elmer LS-50B spectrofluorimeter. $\mathrm{NADP}^{+}(1 \mathrm{mM})$, glutamate dehydrogenase (GDH; 50 units/ $\mathrm{mL})$, and $\mathrm{CaCl}_{2}(1 \mathrm{mM})$ were added after $5 \mathrm{~min}$. After a further 10-min incubation, $3 \mathrm{mM}$ 4-AP was added to depolarize synaptosomes. Glutamate release was monitored by measuring the increase of fluorescence (excitation and emission wavelengths of $340 \mathrm{~nm}$ and $460 \mathrm{~nm}$, respectively) due to NADPH being produced by the oxidative deamination of released glutamate by GDH. Data were accumulated at 2-sec intervals. A standard of exogenous glutamate $(5 \mathrm{nmol})$ was added at the end of each experiment, and the fluorescence change produced by the standard addition was used to calculate the released glutamate as nmol glutamate/mg synaptosomal protein.

\section{Acknowledgments}

This study was supported by the National Health Research Institutes (NHRI-EX92-9202NI), Academic Excellence Program of the Ministry of Education (89-B-FA08-1-4), and China Medical University (CMU92-CI-04).

\section{References}

Anwyl, R. 1999. Metabotropic glutamate receptors: Electrophysiological properties and role in plasticity. Brain Res. Rev. 29: 83-120.

Barrionuevo, G., Schottler, F., and Lynch, G. 1980. The effect of repetitive low frequency stimulation on control and 'potentiated' synaptic responses in the hippocampus. Life Sci. 27: 2385-2391.

Battaglia, G., Monn, J.A., and Schoepp, D.D. 1997. In vivo inhibition of veratradine-evoked release of striatal excitatory amino acids by the group II metabotropic glutamate receptor agonist LY354740 in rats. Neurosci. Lett. 229: 161-164.

Bauer, E.P., Schafe, G.E., and LeDoux, J.E. 2002. NMDA receptors and L-type voltage-gated calcium channels contribute to long-term potentiation and different components of fear memory formation in the lateral amygdala. J. Neurosci. 22: 5239-5249.

Capogna, M., Gahwiler, B.H., and Thompson, S.M. 1996. Presynaptic inhibition of calcium-dependent and -independent release elicited

\section{Learning \& Memory}


with ionomycin, gadolinium and $\alpha$-latrotoxin in the hippocampus. J. Neurophysiol. 75: 2017-2028.

Cho, K., Kemp, N., Noel, J., Aggleton, J.P., Brown, M.W., and Bashir, Z.I. 2000. A new form of long-term depression in the perirhinal cortex. Nat. Neurosci. 3: 150-156.

Heinbockel, T. and Pape, H.C. 2000. Input-specific long-term depression in the lateral amygdala evoked by $\theta$ frequency stimulation. $J$. Neurosci. 20: $1-5$.

Helton, D.R., Tizzano, J.P., Monn, J.A., Schoepp, D.D., and Kallman, M.J. 1997. LY354740: A metabotropic glutamate agonist which ameliorates symptoms of nicotine withdrawal in rats. Neuropharmacol. 36: 1511-1516.

Helton, D.R., Tizzano, J.P., Monn, J.A., Schoepp, D.D., and Kallman, M.J. 1998. Anxiolytic and side-effect profile of LY354740: A potent highly selective, orally active agonist for group II metabotropic glutamate receptors. J. Pharmacol. Exp. Ther. 284: 651-660.

Huang, L., Killbride, J., Rowan, M.J., and Anwyl, R. 1999. Activation of mGluR II induces LTD via activation of protein kinase A and protein kinase $\mathrm{C}$ in the dentate gyrus of the hippocampus in vitro. Neuropharmacol. 38: 73-83.

Impey, S., Smith, D.M., Obrietan, K., Donahue, R., Wade, C., and Storm, D.R. 1998. Stimulation of cAMP response element (CRE)-mediated transcription during contextual learning. Nat. Neurosci. 1: 595-601.

Ishida, M., Saitoh, T., Shimamoto, K., Ohfune, Y., and Shinozaki, H. 1993. A novel metabotropic glutamate receptor agonist: Marked depression of monosynaptic excitation in the newborn rat isolated spinal cord. Br. J. Pharmacol. 109: 1169-1177.

Jane, D.E., Thomas, N.K., Tse, H.W., and Watkins, J.C. 1996. Potent antagonists at the L-AP4- and (1S,3S)-ACPD-sensitive presynaptic metabotropic glutamate receptors in the neonatal rat spinal cord. Neuropharmacol. 35: 1029-1035.

Josselyn, S.A., Shi, C., Carlezon, W.A., Neve, R.L., Nestler, E.J., and Davis, M. 2001. Long-term memory is facilitated by cAMP response element-binding protein overexpression in the amygdala. J. Neurosci. 21: 2404-2412.

Keele, N.B., Neugebauer, V., and Shinnick-Gallagher, P. 1999. Differential effects of metabotropic glutamate receptor antagonists on bursting activity in the amygdala. J. Neurophysiol. 81: 2056-2065.

Kobayashi, K., Manabe, T., and Takahashi, T. 1999. Calcium-dependent mechanisms involved in presynaptic long-term depression at the hippocampal mossy fiber-CA3 synapse. Eur. J. Neurosci. 11: $1633-1638$.

Li, H., Weiss, S.R.B., Chuang, D.M., Post, R.M., and Rogawski, M.A. 1998. Bidirectional synaptic plasticity in the rat basolateral amygdala: Characterization of an activity-dependent switch sensitive to the presynaptic metabotropic glutamate receptor antagonist 2S- $\alpha$-ethylglutamic acid. J. Neurosci. 18: $1662-1670$.

Lin, C.H., Yeh, H.W., Lin, C.H., Lu, K.T., Leu, T.H., Chang, W.C., and Gean, P.W. 2001. A role for the PI-3 kinase signaling pathway in fear conditioning and synaptic plasticity in the amygdala. Neuron 31: $841-851$

Lin, C.H., Lee, C.C., and Gean, P.W. 2003. Involvement of a calcineurin cascade in amygdala depotentiation and quenching of fear memory. Mol. Pharmacol. 63: 44-52.

Lin, H.C., Wang, S.J., Luo, M.Z., and Gean, P.W. 2000. Activation of group II metabotropic glutamate receptors induces long-term depression of synaptic transmission in the rat amygdala. J. Neurosci. 20: 9017-9024.

Lu, K.T., Walker, D.L., and Davis, M. 2001. Mitogen-activated protein kinase cascade in the basolateral nucleus of amygdala is involved in extinction of fear-potentiated startle. J. Neurosci. 21: RC162 (1-5).

Maren, S. 1999. Long-term potentiation in the amygdala: A mechanism for emotional learning and memory. Trends Neurosci. 22: 561-567.

McKernan, M.G. and Shinnick-Gallagher, P. 1997. Fear conditioning induces a lasting potentiation of synaptic currents in vitro. Nature 390: $607-610$.

Miserendino, M.J., Sananes, C.B., Melia K.R., and Davis M. 1990. Blocking of acquisition but not expression on conditioned fear-potentiated startle by NMDA antagonists in the amygdala. Nature 345: 716-718.

Morgan, C.A., Grillon, C., Southwick, S.M., Davis, M., and Charney, D.S. 1996. Aggregated acoustic startle reflex in Gulf War veterans with posttraumatic stress disorder. Am. J. Psychiat. 153: 6468
Nakanishi, S. 1992. Molecular diversity of glutamate receptors and implications for brain function. Science 258: 597-603.

Neki, A., Ohishi, H., Kaneko, T., Shigemoto, R., Nakanishi, S., and Mizuno, N. 1996. Pre- and postsynaptic localization of a metabotropic glutamate receptor, mGluR2, in the rat brain: An immunohistochemical study with a monoclonal antibody. Neurosci. Lett. 202: 197-200.

Neugebauer, V., Keele, N.B., and Shinnick-Gallagher, P. 1997. Epileptogenesis in vivo enhances the sensitivity of inhibitory presynaptic metabotropic glutamate receptors in basolateral amygdala neurons in vitro. J. Neurosci. 17: 983-995.

Otani, S., Daniel, H., Takita, M., and Crepel, F. 2002. Long-term depression induced by postsynaptic group II metabotropic glutamate receptors linked to phospholipase $\mathrm{C}$ and intracellular calcium rises in rat prefrontal cortex. J. Neurosci. 22: 3434-3444.

Paxinos, G. and Watson, C. 1986. The rat brain in stereotaxic coordinates. Academic Press, San Diego, CA.

Pin, J.P. and Duvoisin, R. 1995. The metabotropic glutamate receptors: Structure and functions. Neuropharmacol. 34: 1-26.

Robbe, D., Alonso, G., Chaumont, S., Bockaert, J., and Manzoni, O.J. 2002. Role of $\mathrm{P} / \mathrm{Q} \mathrm{Ca}^{++}$channels in metabotropic glutamate receptor 2/3-dependent presynaptic long-term depression at nucleus accumbens synapses. J. Neurosci. 22: 4346-4356.

Rogan, M.T., Staubli, U.V., and LeDoux, J.E. 1997. Fear conditioning induces associative long-term potentiation in the amygdala. Nature 390: 604-607.

Schafe, G.E., Atkins, C.M., Swank, M.W., Bauer, E.P., Sweatt, J.D., and LeDoux, J.E. 2000. Activation of ERK/MAPK kinase in the amygdala is required for memory consolidation of Pavlovian fear conditioning. J. Neurosci. 20: 8177-8187.

Schafe, G.E., Nader, K., Blair, H.T., and LeDoux, J.E. 2001. Memory consolidation of Pavlovian fear conditioning: A cellular and molecular perspective. Trends Neurosci. 24: $540-546$.

Schaffhauser, H., Richards, J.G., Cartimell, J., Chaboz, S., Kemp, J.A., Klingelschmidt, A., Messer, J., Stadler, H., Woltering, T., and Mutel, V. 1998. In vitro binding characteristics of a new selective group II metabotropic glutamate receptor radioligand, $\left[{ }^{3} \mathrm{H}\right] \mathrm{LY} 354740$, in rat brain. Mol. Pharmacol. 53: 228-233.

Shekhar, A. and Keim, S.R. 2000. LY354740, a potent group II metabotropic glutamate receptor agonist prevents lactate-induced panic-like response in panic-prone rats. Neuropharmacol. 39: 1139-1146.

Soderling, T. and Derkach, V.A. 2000. Postsynaptic protein phosphorylation and LTP. Trends Neurosci. 23: 75-80.

Staubli, U. and Chun, D. 1996. Factors regulating the reversibility of long-term potentiation. J. Neurosci. 16: 853-860.

Tzounopoulos, T., Janz, R., Sudhof, T.C., Nicoll, R.A., and Malenka, R.C. 1998. A role for cAMP in long-term depression at hippocampal mossy fiber synapses. Neuron 21: 837-845.

Walker, D.L., Ressler, K.J., Lu, K.T., and Davis, M. 2002. Facilitation of conditioned fear extinction by systemic administration or intra-amygdala infusions of D-cycloserine as assessed with fear-potentiated startle in rats. J. Neurosci. 22: 2343-2351.

Wang, S.J., Sihra, T.S., and Gean, P.W. 2001. Lamotrigine inhibition of glutamate release from isolated cerebrocortical nerve terminals (synaptosomes) by suppression of voltage-activated calcium channel activity. NeuroReport 12: 2255-2258.

Weisskopf, M.G., Bauer, E.P., and LeDoux, J.E. 1999. L-type voltage-gated calcium channels mediate NMDA-independent associative long-term potentiation at thalamic input synapses to the amygdala. J. Neurosci. 19: 10512-10519.

Wilsch, V.W., Pidoplichko, V.I., Opitz, T., Shinozaki, H., and Reymann, K.G. 1994. Metabotropic glutamate receptor agonist DCG-IV as NMDA receptor agonist in immature rat hippocampal neurons. Eur. J. Pharmacol. 262: 287-291.

Yokoi, M., Kobayashi, K., Manabe, T., Takahashi, T., Sakaguchi, I., Katsuura, G., Shigemoto, R., Ohishi, H., Nomura, S., Nakamura, K., et al. 1996. Impairment of hippocampal mossy fiber LTD in mice lacking mGluR2. Science 273: 645-647.

Received February 20, 2004; accepted in revised form December 15, 2004. 


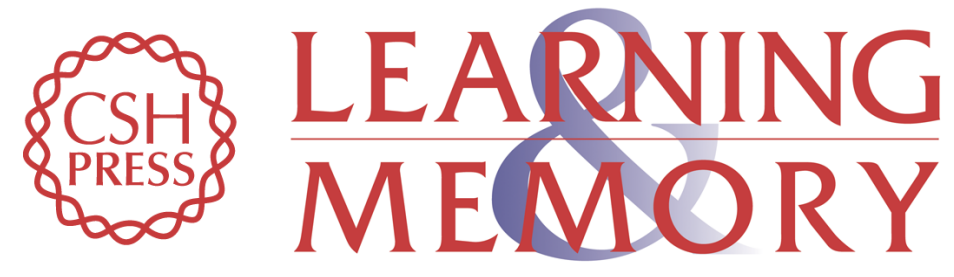

\section{Activation of group II metabotropic glutamate receptors induces depotentiation in amygdala slices and reduces fear-potentiated startle in rats}

Chia-Ho Lin, Chia-Ching Lee, Ya-Chun Huang, et al.

Learn. Mem. 2005, 12:

Access the most recent version at doi:10.1101//m.85304

References This article cites 44 articles, 18 of which can be accessed free at: http://learnmem.cshlp.org/content/12/2/130.full.html\#ref-list-1

License

Email Alerting

Receive free email alerts when new articles cite this article - sign up in the box at the Service top right corner of the article or click here. 